\title{
Resource Complementarity and Value Capture in Firm Acquisitions The Role of Intellectual Property Rights
}

Grimpe, Christoph; Hussinger, Katrin

\author{
Document Version \\ Accepted author manuscript \\ Published in: \\ Strategic Management Journal
}

DOI:

10.1002/smj.2181

Publication date:

2014

License

Other

Citation for published version (APA):

Grimpe, C., \& Hussinger, K. (2014). Resource Complementarity and Value Capture in Firm Acquisitions: The Role of Intellectual Property Rights. Strategic Management Journal, 35(12), 1762-1780.

https://doi.org/10.1002/smj.2181

Link to publication in CBS Research Portal

\section{General rights}

Copyright and moral rights for the publications made accessible in the public portal are retained by the authors and/or other copyright owners and it is a condition of accessing publications that users recognise and abide by the legal requirements associated with these rights.

\section{Take down policy}

If you believe that this document breaches copyright please contact us (research.lib@cbs.dk) providing details, and we will remove access to the work immediately and investigate your claim.

Download date: 26. Apr. 2023 


\section{Resource Complementarity and Value Capture in Firm Acquisitions: The Role of Intellectual Property Rights Christoph Grimpe and Katrin Hussinger}

Journal article (Post print version)

This is the peer reviewed version of the following article: Resource Complementarity and Value Capture in Firm Acquisitions : The Role of Intellectual Property Rights" / Grimpe, Christoph; Hussinger, Katrin. In Strategic Management Journal, Vol. 35, Nr. 12, 2014, s. 1762-1780., which has been published in final form at $\underline{10.1002 / s m j .2181}$.

This article may be used for non-commercial purposes in accordance with Wiley Terms and Conditions for Self-Archiving.

Uploaded to Research@CBS: March 2016 


\section{RESOURCE COMPLEMENTARITY AND VALUE CAPTURE IN FIRM}

\section{ACQUISITIONS: THE ROLE OF INTELLECTUAL PROPERTY RIGHTS}

Christoph Grimpe, Associate Professor, Copenhagen Business School, Department of Innovation and Organizational Economics, Kilevej 14A, 2000 Frederiksberg, Denmark, email: cg.ino@cbs.dk, phone: +45 38152530.

Katrin Hussinger, Associate Professor, University of Luxembourg, Faculty of Law, Economics and Finance, Center for Research in Economics and Management, 162 A, Avenue de la Faïencerie, 1511 Luxembourg, email: katrin.hussinger@uni.lu, phone: +352 4666446404.

Published in the Strategic Management Journal, Vol. 35, 1762-1780. The final version can be found at http://onlinelibrary.wiley.com/doi/10.1002/smj.2181/abstract

\section{ABSTRACT}

Extant literature holds that firm acquisitions create value through innovation if the knowledge bases of the acquirer and the target complement each other. Little is known about the value that patents associated with a target's knowledge convey to the acquirer, i.e. their value in securing market exclusion and freedom to operate in $\mathrm{R} \& \mathrm{D}$. We argue that such property rights hold preemptive power allowing firms to capture the value from combining complementary technologies and to realize gains from trade in strategic factor markets. Our results for a sample of 1428 acquisitions indicate that - controlling for technological value - acquired pre-emptive power is an important determinant of the acquisition price, particularly when the acquirer is technology intensive and acquired patents are highly related to the acquirer's knowledge base.

Keywords: Technology acquisitions, intellectual property rights, value creation, value capture, resource complementarity 


\section{INTRODUCTION}

Firm acquisitions to gain access to technology, knowledge, and capabilities have become a frequently observed corporate trend (Hitt et al., 1996; Ahuja and Katila, 2001; Graebner, 2004; Makri, Hitt, and Lane, 2010). A key concern of prior literature has been to understand the conditions under which these acquisitions increase innovation performance and hence create value for the acquiring firms (Barney, 1988; Hitt, Harrison, and Ireland, 2001). One of the main findings is that acquired knowledge and technology should be complementary to the acquirer's knowledge base (Cassiman et al., 2005), because such a combination leads to a “surplus” over and above the value the acquirer's and target's resources could create independently (Conner, 1991). In other words, technology acquisition creates value when the technological knowledge is sufficiently similar to provide opportunities for learning, but different enough to expose the acquirer to new and diverse knowledge (Ahuja and Katila, 2001; Cloodt, Hagedoorn, and van Kranenburg, 2006).

Anecdotal evidence suggests, however, that acquiring firms might not be primarily interested in the opportunities to learn from a target’s knowledge and technology base, but instead in the opportunity to acquire a contested patent portfolio that either threatens their own research and development (R\&D) activities in a particular field of technology or that could be used to block third parties. A prominent example of an industry in which technology acquisitions are meant not only to accelerate innovation in the merged entity but also to secure important patents is the information and communications technology (ICT) industry. In August 2011, David Drummond, Chief Legal Officer at Google, complained that Google’s success with mobile devices triggered “a hostile, organized campaign against Android by Microsoft, Oracle, Apple 
and other companies, waged through bogus patents. [...] Patents were meant to encourage innovation, but lately they are being used as a weapon to stop it.” ${ }^{1}$ Only a few weeks later, Larry Page, Google’s CEO, announced that Google was to acquire Motorola Mobility, a mobile phone manufacturer that had come under financial pressure: "Our acquisition of Motorola will increase competition by strengthening Google’s patent portfolio, which will enable us to better protect Android from anti-competitive threats from Microsoft, Apple and other companies.” Page further commented that "the combination of Google and Motorola will not only supercharge Android, but will also enhance competition and offer consumers accelerating innovation, greater choice, and wonderful user experiences.”2

Google’s acquisition of Motorola indicates that a firm’s patent portfolio not only represents an independent and observable indicator of its technology base and research capabilities (Henderson and Cockburn, 1994; Adegbesan and Higgins, 2010) but also holds preemptive power that may be valuable to the acquiring firm. By their very definition, patents are intellectual property rights (IPR) that grant a temporary monopoly to commercialize an invention that would otherwise be free for others to use (Arrow, 1962). Besides protecting a specific invention, patents defend a spot in technology space around the patented invention. Since followup inventions need to involve a significant inventive step over the state of the art in order to qualify for patent protection, granted patents influence competition in product markets (Ceccagnoli, 2009). In this paper, we shed light on the pre-emptive power of a target firm's patent portfolio and argue that it may in fact be another source of value - besides the value that

\footnotetext{
${ }^{1}$ http://googleblog.blogspot.com/2011/08/when-patents-attack-android.html

${ }^{2}$ http://googleblog.blogspot.com/2011/08/supercharging-android-google-to-acquire.html
} 
can be created through combining complementary resources and technologies - because it allows acquirers to secure market exclusion and their freedom to operate in $\mathrm{R} \& \mathrm{D}$ and hence to capture value from innovation activities.

From a theoretical perspective, firm acquisitions on the market for corporate control have frequently been characterized as resource acquisitions on strategic factor markets (SFM) (e.g., Barney, 1986, 1988; Lippman and Rumelt, 2003). Extant SFM theory suggests that, since firms’ endowment with resources varies, some firms exhibit superior complementarity to resources available on SFM, i.e. they may create a greater surplus than other firms when acquiring resources on SFM. While the distribution of the surplus is ex-ante indeterminate, firms with superior complementarity may, as a consequence, be guaranteed a minimum level of value appropriation (Adegbesan, 2009). This proposition of value appropriation, however, rests on the implicit assumption that acquiring firms also hold the property rights required for capturing the value. The acquisition of pre-emptive power from a target firm can therefore be understood as a way to unlock complementarity effects that represent the gains from trade in SFM.

By clarifying an assumption of SFM theory, our research aims at understanding the value of acquired patents’ pre-emptive power vis-à-vis the technological value of the target’s knowledge base. Moreover, we are interested in the conditions under which acquiring firms can expect to capture most value. We examine two conditions that affect the value of the target's preemptive power to the acquiring firm: the acquirer's own technology intensity and the relatedness between the acquirer's and target's technology portfolios. We expect the acquirer's technology intensity to have a positive moderating effect on the relationship between the target's preemptive power and the expected value capture since technology intensive firms have relatively large sunk R\&D investments that they seek to protect. Moreover, we suggest that a target's pre- 
emptive power is most valuable when its patents are highly related to the acquirer's patent portfolio because highly related patents make it possible to appropriate value from "locked" technology the acquirer could not commercialize due to competitor patents. Hence, while acquiring firms can expect to create most value due to organizational learning and crossfertilization when combining patent portfolios with a moderate degree of relatedness, value capture is fostered through the acquisition of a target firm's highly related patents.

We investigate our research question in a sample of 1428 firm acquisitions in Europe during the 14-year period from 1997 to 2010. Unlike prior studies in the field that use innovation performance as the dependent variable (e.g., Ahuja and Katila, 2001; Cassiman et al., 2005), our regressions explain the price paid by the acquiring firm for the target. Under the condition of resource competition, the price is a proxy for an acquirer’s “willingness to pay” (Brandenburger and Stuart, 1996) and reflects its expectations for future value creation and capture (Barney, 1988). Excluding managerial hubris, the price thus accounts for differences in the ability of firms to realize gains from trade in SFM (Adegbesan, 2009).

Our study makes three contributions to the literature. First, by focusing on the preemptive power of patents in technology acquisitions, we respond to the claim that the analysis of value appropriation has remained a relatively understudied area in the resource-based view (RBV) (Coff, 1999; Barney, 2001). While the acquisition of technology as a means to create value has received considerable attention in the literature (e.g., Cassiman et al., 2005, Makri et al., 2010), our research disentangles the effects of the technological value of a target’s knowledge base from the pre-emptive power of the associated patent portfolio. Empirically, we rely on newly developed indicators to measure the technological value of the knowledge base and the associated pre-emptive power of patents that build on unique information available from 
the patent examination procedure at the European Patent Office (EPO) (Grimpe and Hussinger, 2008; Guellec, Martinez, and Zuniga, 2012). Second, we clarify an implicit, yet important assumption of SFM theory regarding the appropriation of value in the presence of superior resource complementarity. In its current state of development, SFM theory falls short of accounting for the importance of property rights in capturing value. In other words, acquiring firms that display superior complementarity to target resources can only be guaranteed a minimum level of value appropriation if they hold the property rights necessary to exploit that complementarity. Third, we adopt a contingency perspective and investigate the conditions under which the acquisition of pre-emptive power becomes most valuable to the acquirer. In particular, we argue that highly related or even overlapping patent portfolios can actually be highly valuable if the pre-emptive aspect of patents is considered.

The remainder of the paper is organized as follows. The next section provides some background on the pre-emptive power of patents before we outline our theoretical framework and establish a set of hypotheses. Section 4 introduces our data, measures, and model. We test our hypotheses in section 5 and subsequently discuss the results, outlining implications for management practice and research. The last section concludes, provides a critical evaluation, and points out potential areas for further research.

\section{PATENTS AND VALUE CAPTURE}

Prior research has used patents as observable indicators of the technological value of a firm’s knowledge base (e.g., Ahuja and Katila, 2001; Adegbesan and Higgins, 2010). The larger a firm's patent portfolio, the greater its assumed research capabilities and inventive activity. Larry Page’s remark on "bogus patents” suggests, however, that not all patents filed reflect advances in 
the firm's knowledge base to the same extent. In fact, patent pre-emption, i.e. filing a patent for a substitute of an existing technology before potential competitors to generate a property right, seems to be a widespread strategy of firms to deter the entry of rivals and to capture value (Blind, Cremers, and Müller, 2009; Ceccagnoli, 2009). In order to protect an important invention, firms can "invent around" it by filing patents on close substitutes that do not necessarily represent an improvement over the existing invention. A firm might have no intention to commercialize these inventions but the substitute patents help to build a "patent fence" that forecloses the ability of rivals to file a patent close to the original invention (Cohen, Nelson, and Walsh, 2000; Ziedonis, 2004).

Several recent studies have contributed evidence on this topic. Based on results from the Carnegie-Mellon survey for the United States and Japan, pre-emptive patenting is the most pervasive motive to patent after the prevention of imitation (Cohen et al., 2002). Using survey data from Germany, Blind, Cremers, and Müller (2009) show that more than 40 percent of patenting firms apply for patents in order to block competitors. The authors find particularly striking evidence of "defensive blocking” through patenting. They define this as a forwardlooking protection strategy directed at protecting the firm's position in technology areas and securing its own freedom to operate in R\&D. Ziedonis (2004) analyzes the conditions under which firms patent more aggressively to avoid being “fenced in” by rivals. Ceccagnoli (2009) finds that pre-emptive patenting significantly increases the degree to which firms can appropriate the returns from R\&D. Investigating the market entry of software products, Cockburn and MacGarvie (2011) conclude that patents may deter entry above and beyond the extent to which they mirror the technological capabilities of the firm creating the patents. Although pre-emptive patents may only protect marginal technological change (Guellec et al., 2012), they increase their 
owners' market value significantly, suggesting that the pre-emptive power of a patent portfolio is a significant value determinant (Grimpe and Hussinger, 2008; Czarnitzki, Hussinger, and Leten, 2011). It is less clear, however, under which conditions pre-emptive patents are most valuable for an acquiring firm.

These findings hold two important insights for our research. First, pre-emptive patenting is a significant determinant of the extent to which a firm can appropriate, or capture, the value from its technological innovations and firms will therefore strive to generate or acquire these property rights. Second, firms may differ not only in their technological capabilities but also in their ability to protect important inventions by filing patents for substitutes (or “bogus patents”) to deter R\&D rivals. As a result, the patent portfolio associated with a firm’s knowledge base serves as an indicator not only of a firm's technological capabilities but also of its pre-emptive power. Depending on the firm's IPR strategy, patent portfolios of the same size may hence differ in terms of their technological value and their pre-emptive power. Just as the combination of technological capabilities in a merged firm is expected to create value, we argue in the following that acquiring firms can expect to capture value when they get access to another firm's preemptive power and that this value also depends on the acquirer's own patent portfolio.

\section{THEORY AND HYPOTHESES}

\section{Target valuation with heterogeneous resource complementarity}

One of the key tenets of the RBV is that superior firm performance originates from deploying valuable resources that are rare, difficult to imitate, and non-substitutable (Barney, 1991; Peteraf, 1993). Despite the focus of the resource-based theory on the in-house development of complex 
resources that fulfill these criteria, firms actually make considerable efforts to acquire those resources through mergers, acquisitions, alliances, and other activities, and to combine them with internal resources (e.g., Lippman and Rumelt, 2003; Rothaermel and Boeker, 2008; Grimpe and Kaiser, 2010). It is therefore important to ask at what cost firms can acquire valuable resources. In his SFM theory, Barney $(1986,1988)$ suggests that, assuming an efficient market for corporate control, the price of a target firm is likely to approximate the value it creates for the bidding firm. The cost of the resources will only be lower than their economic value to the acquirer if the acquirer (1) has superior information about their future value, (2) displays superior complementarity to target resources, or (3) is plain lucky. If none of these conditions applies, other bidding firms that see an opportunity for value creation would drive up the price.

Particularly the condition of superior complementarity to target resources has received attention in subsequent contributions to SFM theory. Since firms are differently endowed with resources, some combinations of acquirer and target resources will create more value than others. A bidding firm can hence afford to pay a price over and above the value of the target resource in isolation (Conner, 1991; Lippman and Rumelt, 2003). Applying a game-theoretical model, Adegbesan (2009) shows that, as a consequence, some firms can outbid firms with less resource complementarity, even if all potential bidding firms know ex-ante how much value can be created. More formally, heterogeneous resource complementarity suggests that the combined value of the acquiring firm's resources $v(\mathrm{~A})$ and the target firm's resources $v(\mathrm{~T})$ is $v(\mathrm{~A} \cup \mathrm{T})=$ $v(\mathrm{~A})+v(\mathrm{~T})+S_{A, T}$, where $S_{A, T}>0$. The amount of the surplus $S_{A, T}$ depends on the level of complementarity between both firms’ resources. Therefore, acquiring firms can realize gains from trade in SFM even if they have to pay $p(\mathrm{~T})=v(\mathrm{~T})$ for the target firm because $p(\mathrm{~T}) \leq v(\mathrm{~T})+$ $S_{A, T}$. Since the surplus does not pertain to either the acquirer or the target but instead results from 
their combination, the exact distribution of the surplus is ex-ante indeterminate. However, Adegbesan (2009) further shows that acquiring firms with superior resource complementarity can be guaranteed a minimum level of value appropriation $\left(S_{A, T}>0\right)$ relative to an acquirer that displays least complementarity to a target firm's resources $\left(S_{A, T}=0\right)$. The split of the residual surplus will be determined by a mixture of competition and bargaining ability.

This reasoning is intriguing, since it explains why firms trade technology on SFM even though such resources might be homogeneous and not unique (Lippman and Rumelt, 2003). But it rests on the assumption that the acquiring firm also gets access to the property rights, such as the patents on technology, required to capture the value created. Property rights render the acquired resources and the combination with existing resources unique and grant the right to exclude third parties from using the protected resources. Moreover, some combinations of existing and acquired property rights may be particularly suitable to protect resources. In other words, property rights may be complementary in enabling value capture in resource acquisitions on SFM. While extant SFM theory seems to overlook this problem, the notion of property rights defining a resource owner's ability to create and appropriate value from the resource is not new. Building on insights from property rights economics (e.g., Alchian and Demsetz, 1973), Foss and Foss (2005) stress that the protection of resource value goes beyond making resources difficult to imitate and substitute by competitors (Teece, 1986). Although superior resource complementarity may be difficult to imitate by competitors, those resources are not protected from value erosion unless the resource owner owns the property rights required to commercially exploit such complementarity. Value erosion in that sense refers to a decay in resource value caused by rivals’ ability to interfere with the firm’s value capture (Foss and Foss, 2005). 
Acquiring the property rights to the attributes that define the resources, however, incurs transaction costs that inevitably influence resource value (Foss and Foss, 2005). At the same time, those property rights may be a second source of value - besides the value that stems from complementarity - which has not been documented explicitly in the theoretical literature or at all in the empirical literature on SFM. In that sense, a patent is valuable over and above the value of the technological knowledge since it constitutes a property right that restricts a competitor's ability to interfere with the acquiring firm's value appropriation and protects the resource from value erosion. A firm will therefore choose to acquire the property right if the benefits from owning it outweigh the transaction costs of the exchange. As a consequence, an acquiring firm's willingness to pay for a target depends on the potential not only to create but also to appropriate the value at which owning the property rights on technological knowledge becomes crucial. Patents and their pre-emptive power will thus extend the bargaining range upwards, which relieves pressure on the price and may cause it to increase. Based on the above arguments, the following hypotheses will elaborate on the mechanisms that explain the link between the preemptive power of a target firm's patents and the price paid by the acquirer for the target.

\section{Hypotheses}

The benefits of owning the property rights to technological knowledge and its synergistic recombination depend directly on the competitive context, since the patent portfolio of competitors influences the extent to which firms can commercialize their own inventions. Patents with high pre-emptive power held by competitors can threaten a firm's value capture for several reasons. First, competitors can create significant barriers to entry into particular fields of technology and block other firms from patenting a competing alternative technology. In this regard, the freedom to operate in R\&D becomes restricted by “patent fences” (Ziedonis, 2004). 
Second, the patents held by competitors can force firms into unfavorable licensing negotiations and cross-licensing agreements in order to obtain the property rights required for commercialization (Cohen et al., 2000).

As a result, firms might use an acquisition as a means not only to get access to valuable knowledge and technology but also to access the pre-emptive power of the patent portfolio associated with the target's knowledge base (Grimpe and Hussinger, 2008). The price that the acquirer is willing to pay for the target can be expected to increase with the pre-emptive power of its patents for two reasons. On the one hand, owning the property rights to technological resources ensures their inimitability on legal grounds. By their very definition, patents are temporary monopoly rights that prevent the resource value from eroding (Arrow, 1962). The higher the pre-emptive power of the patents, the lower the ability of competitors to imitate valuable technologies and thus the higher the value the firm will be able to capture. On the other hand, the acquired pre-emptive power facilitates value capture because acquiring firms might be in a better bargaining position in cross-licensing negotiations. On the basis of the exchange of licenses, the acquirer can therefore more easily commercialize inventions and appropriate the returns from its R\&D activities. As a consequence of both arguments, the acquirer will be willing to pay a higher price for the target. Even if the acquired patents are not essential for the acquirer's commercialization activities, patents with high pre-emptive power allow the acquirer to capture value since they may be sold or licensed-out after the transaction. As a result, our first hypothesis reads:

Hypothesis 1: There is a positive relationship between the pre-emptive power of the target firm's patent portfolio and the price paid for the target by the acquiring firm. 
Besides the main effect of the pre-emptive power on the acquisition price, we suggest that two factors may particularly influence the value of pre-emptive patents for an acquirer: the acquirer's own technology intensity and the relatedness between the acquirer's and the target's technology portfolios. In that sense, we expect the technology intensity of the acquirer to have a positive moderating effect on the relationship between the target's pre-emptive power and the acquisition price. The main reason for this expectation is that value creation in technology-intensive firms relies on technological innovation. These firms are more dependent on their R\&D investments, which are basically irreversible and sunk. Moreover, R\&D projects are typically long-term commitments that involve technology and market related risks and hence have an uncertain outcome (Oriani and Sobrero, 2008). Since the potential for value erosion is consequently higher, the costs of being blocked or locked-in by competitors are likely to increase with the firm's technology intensity. Technology-intensive firms have higher incentives to protect their own ongoing R\&D activities by erecting a patent fence of potential substitute patents (Ziedonis, 2004), either by filing those patents themselves or by means of the acquisition. In that sense, the expected value capture from the acquired pre-emptive patents is highest when the acquirer's technology intensity is high since firms avoid the erosion of the value created through innovation. Thus, we propose:

Hypothesis 2: The impact of the pre-emptive power of a target firm's patent portfolio on the price paid for the target by the acquiring firm increases with the acquiring firm's technology intensity.

Finally, we suggest that the relatedness of technologies matters for the value of a target's preemptive power for an acquiring firm. Recall that prior literature suggests that value creation through complementarity results from a moderate degree of relatedness between the acquirer's 
and target's knowledge bases (Ahuja and Katila, 2001; Cassiman et al., 2005; Cloodt et al., 2006). The absorptive capacity argument (Cohen and Levinthal, 1990) states that the more related the knowledge bases are, the more easily acquired technology can be integrated and commercialized. Similarity facilitates the integration of new knowledge because both the acquirer and the target firm share skills, languages, and cognitive structures that allow firms to learn from each other (Kogut and Zander, 1992; Makri et al., 2010). Integrating related knowledge thus creates value for two reasons. First, it allows firms to apply the acquired knowledge to old problems or a combination of acquired and existing knowledge to those problems. Second, it enables firms to search for and absorb additional knowledge from the environment (Cohen and Levinthal, 1990). However, these benefits only materialize if the relatedness between the acquirer's and target's knowledge bases is not too high because the opportunities to learn decrease with increasing relatedness after a certain point (Ahuja and Katila, 2001).

While these arguments provide useful guidance for value creation, relatedness is likely to play a different role when the pre-emptive power of the target's patents is considered. We suggest that the value captured by the acquirer is likely to increase monotonically with the relatedness to the target firm's patents. Acquiring firms benefit from higher relatedness because the acquired pre-emptive power creates a patent fence directly around the firm's own R\&D activities. In that sense, it helps to protect the firm's sunk investments in $R \& D$, to secure the firm's freedom to operate in R\&D, and to exclude competitors from certain technological spaces. Hence, increasing relatedness reduces the threat of value erosion. Moreover, firms may want to acquire highly related patents with high pre-emptive power in order to unlock an existing patent fence that hinders the acquirer's value appropriation. As a result, such an acquisition would 
enable the acquirer to continue or expand ongoing R\&D work (Graff, Rausser, and Small, 2003) and to unlock the complementarity effects that represent the gains from trade in SFM. The value that the acquirer may be able to capture by combining its own knowledge base with the preemptive power of the patents held by the target firm is consequently highest if the technology and patent portfolios are highly related or even largely overlapping in technology space. Although a single acquisition may not be sufficient to rule out the threats imposed by the patent positions of competitors, the acquirer can still expect to capture a higher share of value if it succeeds in acquiring highly related patents with high pre-emptive power. Hence, our final hypothesis reads as follows:

Hypothesis 3: There is a positive linear relationship between the relatedness of the acquiring firm's knowledge base and the pre-emptive power of the target firm's patent portfolio and the price paid for the target by the acquiring firm.

\section{METHODS}

\section{Data}

We use data from the M\&A database ZEPHYR, which is published by Bureau van Dijk. ZEPYHR is one the most comprehensive databases of deal information, covering more than 900,000 worldwide transactions since 1996. Deals were selected on the basis of the following criteria: First, we restricted the sample to majority acquisitions in the period from 1997 to $2010 .^{3}$ Although the acquisition of a minority share might offer the acquirer significant influence on the

\footnotetext{
${ }^{3}$ The year 1996 was excluded because Bureau van Dijk cautions against a limited coverage of transactions during ZEPHYR's first year of existence.
} 
target, only majority acquisitions in which the acquirer takes control over the target will provide the acquiring firm with the opportunity to combine and integrate the acquired technology. Second, we excluded deals in which either the acquiring or the target firm were located outside Europe. This restriction is necessary because of our choice to use patent data from the European Patent Office (EPO), which will be explained in further detail below. ${ }^{4}$ Third, we restrict the sample to deals in which both the acquiring and the target firm are affiliated with an industry classified as technology or knowledge intensive by Eurostat, the statistical office of the European Union $^{5}$, since knowledge and patented technology are essential for firm success in these industries (Hitt et al., 2006). Finally, we excluded transactions for which either multiple acquirers or targets were listed because the complexity of such deals might confound the effects measured.

Our sample is complemented with balance sheet data for the acquirer and target firms from Bureau van Dijk’s AMADEUS database. Moreover, we linked the firms to their patent filings at the European Patent Office using the PATSTAT database and the OECD patent citation database. On the basis of a computer-supported, text-based search algorithm, firms and granted patents were linked to each other using firm names and addresses in both databases. Each potential match proposed by the search engine was checked manually. It turns out that not all firms involved in the transactions possess patents. Restricting the sample to those transactions with patents involved, i.e. in which either the acquirer or the target have a patent, results in a final sample of 1428 transactions.

\footnotetext{
${ }^{4}$ There may be a home bias in patenting as firms are more likely to apply for patents at the patent office of their home country rather than at other patent offices (Dernis and Khan, 2004).

${ }^{5}$ See http://epp.eurostat.ec.europa.eu/cache/ITY_SDDS/Annexes/htec_esms_an3.pdf
} 


\section{Measures}

\section{Dependent variable}

The dependent variable is the price paid by the acquirer for the target firm. Following Barney (1988), the price $p(T)$ approximates the value of the target when it is combined with the bidding firm. In this regard, the price reflects the acquiring firm's expectations of resource complementarity. Under the condition of heterogeneous resource complementarity across potential bidding firms, the firm with the highest expected resource complementarity can outbid other firms and acquire the target. Since the variable is highly skewed, we take its natural logarithm.

\section{Explanatory variables}

Our hypotheses build on the pre-emptive power of a target firm’s patent portfolio. Disentangling the pre-emptive power of a patent portfolio from a firm's knowledge base is difficult since a patent reflects not only an intellectual property right over an invention but also the fact that new knowledge has been generated as the outcome of an R\&D investment. Some authors have used subjective survey data to identify pre-emptive patenting (e.g., Ceccagnoli, 2009). Our identification relies instead on detailed information available from the patent examination process at the EPO. Specifically, we exploit the fact that patent applications must acknowledge “prior art”, in which light they need to meet the requirements for patentability, i.e. they are novel enough, involve an inventive step, and are susceptible to industrial application (Harhoff, Hoisl, and Webb, 2005). There is ample empirical evidence that prior art that receives a large number of citations in patent applications ("forward citations") is technologically more important and also economically more valuable (e.g., Trajtenberg, 1990; Harhoff et al., 1999; Hall, Jaffe, and 
Trajtenberg, 2005). Recent contributions in the literature on patent indicators have suggested that the examination process at the EPO allows a closer look at those patent citations (e.g., Harhoff and Reitzig, 2004; Grimpe and Hussinger, 2008; Guellec et al., 2012). In other words, information from the EPO can be used in order to determine why a particular patent has been cited in a patent application. The information stems from a so-called "search report", prepared by a patent examiner for each EPO patent application, which lists all important documents that are considered to be prior art. The search for prior art follows the Guidelines for Examination in the European Patent Office ${ }^{6}$ in order to ensure that each patent application is scrutinized under the same quality standards. Patents are generally cited because they affect the patentability of new inventions (Harhoff et al., 2005), but the information in the search report allows a distinction between conflicting and relevant non-infringing prior art (Michel and Bettels, 2001). Conflicting prior art threatens the novelty requirement of the patent application while other relevant prior art provides the non-infringing state of the art in the respective field of technology.

In this regard, a reference to prior art is marked with an " $\mathrm{X}$ " in the search report if the invention in question cannot be considered to be novel or cannot be considered to involve an inventive step when the referenced document is taken into consideration. References are marked with a "Y" if the invention cannot be considered to involve an inventive step when the referenced document is combined with one or more other documents of the same category in a combination obvious to a person skilled in the art (Harhoff et al., 2005; Guellec et al., 2012). A patent application can still be granted (although this is less likely) if it has some references classified with an $\mathrm{X}$ or a Y. This can be the case for patent applications with several claims. XY-

\footnotetext{
${ }^{6}$ See http://www.epo.org/law-practice/legal-texts/guidelines.html
} 
type references may only pertain to single claims and the remaining claims can be strong enough to get a (modified) application granted. In a similar vein, references are marked with an "A” if the cited patents define the state of the art in a technology field but do not threaten the novelty of the patent application. Prior art receiving A-type references are key contributions in a certain technology field and constitute the basis for future inventive activity (Harhoff et al., 2005; Guellec et al., 2012). Hence, XY-type references refer to conflicting prior art while A-type references indicate relevant prior art. On the basis of the list of prior art summarized in the search report a decision is made as to whether a patent application is novel enough and involves an inventive step so that it can be granted.

Figure 1 provides a highly simplified overview of this procedure. We assume that patents A, B, and C are held by a potential target firm. All three patents are cited by an incoming patent application D as prior art. In the example, the reference to patent A was made by the applicant while the references to patents $\mathrm{B}$ and $\mathrm{C}$ were added by the patent examiner. In contrast to the procedure at the United States Patent and Trademark Office (USPTO), most references (about 90 percent) for EPO patent applications are added by the patent examiner rather than by the applicant (Criscuolo and Verspagen, 2008). In the search report, the patent examiner evaluates the importance of prior art for a particular claim by assigning a code letter $\mathrm{X}$, Y, or A (for a full description see Harhoff et al., 2005). ${ }^{7}$

\footnotetext{
${ }^{7}$ An example of this is a patent application filed in 1994 by IBM (application no. EP19940105877). In the search report, the patent examiner lists Motorola's patent no. EP1989113865 and assigns an X-type reference to the first claim in IBM's application and a Y-type reference to claims 2 through 12. In his letter to the applicant, the examiner explains that, in the light of Motorola's patent, IBM's application does not appear to involve an inventive step. In its reply to the patent office, IBM suggests new claims and declares that they were delimited with regard to Motorola's patent. Although IBM's application was eventually granted, it had to be limited in scope, offering less protection for the applicant. Another example is IBM's application no. EP2000114376, which cites Motorola’s patent filing no. EP1996102457. The examiner classifies this reference, which pertains to most of the 74 claims, as a Y-type. As the applicant did not submit a revised application, the application was deemed withdrawn
} 


\section{[Insert Figure 1]}

In order to determine the pre-emptive power of the target firm's patent portfolio, we take the stock of XY-type citations that the target's patent portfolio receives as a share of the total citation stock. ${ }^{8}$ Citation stocks are calculated in analogy to the patent stock (see equation (1) below). We only consider citations that a patent receives in a five-year window after it has been granted as is common in the literature (e.g., Makri et al., 2010). ${ }^{9}$ XY-type citations provide direct evidence that claims in patent applications were actually blocked by the target firm's patents because they invalidated the novelty or inventiveness of the claims. Guellec et al. (2012) show that applications citing prior art classified as an XY-type have a significantly lower likelihood of being granted than those citing an A-type prior art. Such applications are also more often withdrawn by the applicant before the EPO has made a decision. They conclude that XY-cited patents exhibit higher pre-emptive power than other patents. Moreover, they find that those patents contribute little to the state of the art, indicated, for example, by a lower number of claims made, fewer inventors involved, a higher number of self-citations, and a higher number of citations made by themselves (“backward citations”) (Gambardella, Harhoff, and Verspagen,

by the EPO and hence failed. The search report also lists patent no. EP1993480143, which was filed by IBM itself. The reference to this patent, which pertains to all 74 claims, is classified as an A-type. The examiner does not believe that this patent threatens the application. Instead, the reference is necessary to understand the technical background and state of the art. Hence, we can conclude that Motorola's patents had pre-emptive power that limited the patentability of subsequent patent applications. The patent history, including all communications between the EPO and the applicant, is available from the European Patent Register (http://register.epo.org).

\footnotetext{
${ }^{8}$ Patents can receive both XY-type and A-type citations (as well as other citations, see Harhoff et al., 2005, for details), although this is less frequent. In other words, cited patents can be both conflicting and relevant prior art to different or even the same claims in applications. For this reason, it would be inappropriate to take the number of "pre-emptive patents" held as a measure of pre-emptive power since all patents have varying degrees of pre-emptive power. Instead, we focus on the number of XY-type citations that an entire patent portfolio receives.

${ }^{9}$ Patent equivalents, i.e. if a particular invention is patented at two different patent offices, are taken into account. If patent equivalents were ignored, the number of forward citations a patent receives would be significantly underestimated (Harhoff et al., 2005).
} 
2008). In fact, several recent contributions use XY-type citations as indicators of pre-emptive patenting (e.g., Harhoff and Reitzig, 2004; Harhoff, von Graevenitz, and Wagner, 2008). To sum up, the pre-emptive power of a patent portfolio, as evidenced by XY-type citations, can be characterized as a separate value component in addition to the actual technological value of the knowledge base.

Technology intensity of the acquirer. We assume that firms with higher technology intensity can be characterized by a higher number of patents employed in relation to their total assets. Consequently, we calculate the patent stock $P S$ of the acquiring firm as follows:

$P S_{t}=P S_{t-1}(1-\delta)+$ granted patents $t$

where $t$ refers to the year prior to the acquisition and $\delta$ is a constant knowledge depreciation rate of $\delta=15$ percent to weight the importance of older patents as is standard in the literature (e.g., Hall, 1990). The patent stock is then divided by the firm's total assets (in millions of Euros). To test hypothesis 2, we create an interaction term between the target's pre-emptive power and the acquirer's technology intensity.

Technological relatedness. Our measure of relatedness is based on the proximity measure introduced to the patent literature by Jaffe (1986). It captures the extent to which two firms develop technology in the same classes. We use the International Patent Classification (IPC) to define the distribution of the targets' and acquirers’ patents across different technology areas. 
Following recent literature, we use the three-digit IPC level (Makri et al., 2010) ${ }^{10}$ and generate one patent stock measure per three-digit IPC class on the basis of equation (1). Equation (2) below provides the definition of the relatedness measure. Relatedness is defined as the angular separation of the patent class distribution vectors $F$ of the acquirer $j$ and the target firm $i$. The technology vectors $F$ for each target $i$ and acquirer $j$ can be interpreted as their technology portfolio. We use these vectors as a percentage of the total patent stock in order to leave out patent portfolio size differences between the target and acquirer patent portfolios. In technical terms the relatedness measure $T$ equals the scalar product of these vectors normalized by their scalar products with themselves, so that the measure takes the value of one for any two identical technology vectors:

$T_{i j}=\frac{F_{i} F_{j}}{\sqrt{\left(F_{i}^{\prime} F_{i}\right)\left(F_{j}^{\prime} F_{j}\right)}} \times 100 ; \quad 0 \leq T_{i j} \leq 100$

where zero represents no overlap of the firms’ patent portfolios and a value higher than zero indicates some overlap.

To test hypothesis 3, we calculate the relatedness measure on the basis of the two different patent portfolio components. Following on from the above discussion, the relatedness measure is applied to the target's patents cited as pre-emptive (XY-type) and to the acquirer's patents cited as contributing to the state of the art (A-type). We use fractional counting in case a patent is cited as both an XY- and an A-type. We refer only to the acquirer's A-type cited patents

\footnotetext{
${ }^{10}$ Since the IPC is a hierarchical system, the first digit is the section symbol, followed by two digits that denote the class. The one-digit technology class C, for example, refers to chemistry, and the subclass C07 denotes organic chemistry while subclass C08 stands for organic macromolecular compounds. See the classification published by the World Intellectual Property Organization (WIPO), http://www.wipo.int/classifications/ipc/en/.
} 
since those patents have been cited as presenting the state of the art in a field of technology (Guellec et al., 2012). In other words, those patents actually represent the technological "quality" of a firm's knowledge and technology base. We use the relatedness measure in a linear and a squared term and expect only the linear term to become significant in the regression.

\section{Control variables}

We control for a number of factors that may affect the price paid for the target firm. First, we include the total patent stock of the target firm normalized by the target's total assets (in millions of Euros) to control for the extent that knowledge is protected through patents by the target. The patent stock is calculated on the basis of equation (1). Since the value of patents is highly skewed (Harhoff et al., 1999), we control for the value of those patents by including the stock of forward citations the target's patents received in a five-year window after the grant. As the number of citations a firm receives is highly correlated with its patent stock, we divide the citation stock by the target's patent stock. The models testing hypothesis 3 also include a linear and a squared term of the relatedness measure. In one specification, the measure is based on both the acquirer's and the target's patent portfolios; in a second specification, it is based on both firms' A-type cited patents. This enables us to compare our results with prior literature that found an inverse Ushaped relationship for the relatedness between the acquiring and target firms’ knowledge bases (Ahuja and Katila, 2001).

Regarding the non-technological assets, we include the total assets of the target (in millions of Euros) to control for its size. Moreover, we include the target's return on assets, defined as the sum of profits earned by the firm and the capital gains of assets over total assets, as well as its financial leverage measured as liabilities over total assets. As the variable for 
liabilities is missing in some cases, we include a dummy variable that takes a value of one in the case of missing liabilities and zero otherwise. Liabilities are set to zero if missing. Further, we include the target firm’s age measured in years.

Our model further includes a dummy variable that takes the value of one if both the acquirer and the target are in the same two-digit NACE industry class. ${ }^{11}$ To control for differences between domestic and international transactions we include a dummy variable that takes a value of one in the case of a cross-border deal. Finally, we control for time effects by including year dummies for the years from 1997 to 2009, with 2010 being the reference category, and we include six industry dummies for the target, which are defined on the basis of the Eurostat industry aggregation according to the technology intensity of the sector: high-tech, medium high-tech, medium low-tech, and low-tech manufacturing, as well as knowledgeintensive and low knowledge-intensive services. High-tech manufacturing is the reference category in our estimations. All explanatory and control variables refer to the year prior to the completion of the acquisition to control for potential endogeneity.

\section{Model}

We follow Hall et al. (2005) and estimate a market value function with separable components of the total value. In our case, the value of a target firm is a function of its technological and nontechnological assets, the complementarity between the acquirer's and the target's resources, and other transaction-specific controls. Patents, citations, and the type of citations are used as

\footnotetext{
${ }^{11}$ NACE stands for "Nomenclature statistique des activités économiques dans la Communauté européenne” and is a European industry standard classification system consisting of a six-digit code. It is similar in function to the SIC or NAICS systems.
} 
cascading indicators of the value of the technological assets, "each adding further information on top of what could be predicted on the basis of the previous indicator” (Hall et al., 2005: 27). For this reason, we use the target's patent stock over total assets, the citation stock over the patent stock, and the stock of XY-type citations over the citation stock in our model specification to account for the target's technological assets. Using such cascading indicators also avoids collinearity problems. Since the price paid by the acquirer is a continuous variable, our model can be estimated by ordinary least squares (OLS). Besides the baseline model, which only includes the control variables, we use several specifications to test our hypotheses.

\section{RESULTS}

\section{Descriptive statistics}

Table 1 presents summary statistics. The average acquisition price equals 458 million Euros while the average total assets of the target are 684 million Euros. Target firms have an average patent stock of 3.49 patents, compared to the almost 50 patents that the acquirers hold. On average, the targets’ patent stock receives 0.86 citations within a five-year window after being granted. With regard to the relatedness variables we find that our sample is quite balanced. On average, deals show the same average relatedness for the knowledge base and the pre-emptive

power. ${ }^{12}$ Moreover, it turns out that 43 percent of the transactions in the subsample of deals are international transactions and 45 percent of the transactions occur in the same industry. Target firms are on average 34 years old, indicating that our sample is not dominated by young,

\footnotetext{
${ }^{12}$ Note that the relatedness of the technology portfolios is, on average, quite low. This is due to the choice of the three-digit IPC level to calculate this measure.
} 
innovative start-up companies that get acquired soon after inception. Interestingly, target firms on average exhibit a negative return on assets. There are no indications of collinearity problems in our data as evidenced by the rather low correlations among the explanatory variables.

\section{[Insert Table 1]}

\section{Multivariate analysis}

Table 2 shows the results of the OLS estimation in three different model specifications to test our hypotheses. The first specification serves as a benchmark model to show the effects of the firm and transaction characteristics and the technology measures, our control variables, on the acquisition price. The estimated coefficients largely show the expected signs. Regarding the nontechnology variables, we find a positive effect of the target firm's total assets, return on assets, and age on the acquisition price. The effect of the return on assets intuitively makes sense, as more profitable targets provide more opportunities to recover the acquisition price. The positive age effect can be interpreted as the value of the target firm's goodwill, market access, reputation, etc. which have been developed over time. As expected, the acquisition price decreases the higher the financial leverage of the target firm. Furthermore, cross-border acquisitions turn out to be more expensive than domestic acquisitions, suggesting that the acquirer is paying a higher price to gain access to a foreign market. There is no significant effect for intra-industry takeovers. With regard to the technology control variables, it turns out that the patent stock over assets has a negative effect. This result might seem counterintuitive but the variable for the technological value of patents, as measured by the number of citations received over the patent stock, suggests a positive effect of high quality patents on the price paid, as suggested in the literature (Harhoff et al., 1999). This finding might also be related to the fact that an acquirer is 
more likely to choose market-based solutions like (cross-)licensing and trading patents with a target holding a large patent portfolio rather than choosing an acquisition (Graff et al., 2003). Finally, while the year dummies are jointly significantly different from zero, as LR-Chi ${ }^{2}$ tests show, the industry dummies are not. This finding suggests some changes in target valuation over time, as would be expected from casual observation of the stock market. The effects of the control variables are consistent across all specifications.

Model 2 includes our measure of the pre-emptive power of the target's patent portfolio. We find a strong positive effect, i.e. the pre-emptive power impacts significantly on the acquisition price, and we can thus confirm the first hypothesis. Model 3 includes the acquirer's technology intensity, measured as the acquirer's patent stock over total assets, as well as the interaction term with the target's pre-emptive power. While the acquirer's technology intensity does not in itself have an effect on the acquisition price (as expected), we find a strongly significant and positive interaction effect. This finding indicates that the higher the acquirer's technology intensity, the more valuable the target's pre-emptive power. Hence, we can confirm the second hypothesis.

\section{[Insert Table 2]}

Model 4 includes the non-differentiated relatedness measure based on the entire patent portfolio of the acquirer and the target firm as well as its squared term. We find an inverse U-shaped relationship between the degree of technological relatedness and the acquisition price, which suggests that the acquisition price can be regarded as an indication of the value that the acquiring firm expects to create through innovation (Barney, 1988). Model 5 is used to test hypothesis 3. The measure of the relatedness of the technology portfolios is now differentiated according to the 
two different types of citations that the acquirer's and the target's patent portfolios have received. Our results substantiate the inverse U-shaped relationship for the relatedness between the patent portfolio components that actually measure the technological value of the patents, i.e. the A-type cited patents. Apparently, value creation expected by the acquirer increases up to a certain point of relatedness of the technology portfolios and decreases if relatedness becomes too high. When the relatedness between the A-type cited patents of the acquirer and the XY-type cited patents of the target (i.e. its pre-emptive power) is considered, it turns out that the relationship increases monotonically. Hypothesis 3 thus receives support. This finding suggests that the value of the pre-emptive power of the target's patents in fact increases with increasing relatedness to the acquirer's patent portfolio and is not subject to decreasing value if relatedness becomes too high. In that sense, the inverse U-shaped relationship requires an important qualification, depending on whether the technological value or the pre-emptive power of the target's patent portfolio is considered. The different estimated effects found for A-type and XYtype citations in terms of relatedness are depicted in Figure $2 .^{13}$

\section{[Insert Figure 2]}

\footnotetext{
${ }^{13}$ To further analyze the inverse U-shaped relationships found in both model 4 and model 5 we conduct simple slope analyses and additional robustness tests (Aiken and West, 1991; Cardinal, Miller, and Palich, 2011). The turning point lies within the data range for each model. Further, the inverse U-shape is not driven by our choice of functional form for the variable of interest. Alternative specifications using dummy variables as well as the polynomial series of the variable of interest support an inverse Ushaped relationship. While the inverse U-shaped relationship receives strong support for model 5, it finds less support for model 4. This is to be expected because model 5 disaggregates the relatedness measure from model 4 and finds both a squared and a linear effect if different patent portfolio components are considered. Moreover, the results for our main variables persist if we run the regression with a limited set of control variables. Hence, there are no suppression or enhancement effects due to our control variables. All additional analyses are available from the authors upon request.
} 
The two remaining model specifications test for the consistency of the results. In this regard, the findings show that the linear relationship persists if the squared term of the relatedness measure is included. Moreover, the findings are consistent when all model variables are included. ${ }^{14}$

\section{DISCUSSION}

Under what conditions do acquiring firms benefit from the acquisition of technology in an M\&A transaction? The answer prior literature has provided centers on the concept of complementarity, understood as a moderate degree of overlap between the knowledge and technology portfolios of the acquiring and the target firm (e.g., Ahuja and Katila, 2001; Makri et al., 2010). Extant SFM theory suggests that firms exhibiting superior complementarity to resources available on SFM may create a greater surplus than other firms whose resources are less complementary to those acquired. In that case, acquiring firms can also be guaranteed to capture at least a part of the value created through complementarity. This conclusion rests on an implicit, yet important assumption that the research presented here seeks to clarify. We demonstrate that acquiring firms' value capture depends on getting access to the relevant property rights. In that sense, we argue that extant literature has largely overlooked the fact that the pre-emptive power of an acquired firm's patent portfolio associated with its knowledge base can be an important source of value. While acquiring firms can create value through acquired technology moderately related to the firm's own technology, because such a combination drives

\footnotetext{
${ }^{14}$ Our analysis implicitly assumes that it matters whether the acquirer or the target owns the patents with pre-emptive power that the other party is interested in. However, one could also argue that the suggested relationships hold in a reciprocal way, i.e. combining an acquirer's pre-emptive power with a target's knowledge base allows the merged entity to capture value in a similar way to the reverse situation. However, our results, which are available from the authors upon request, show that this is not the case. We attribute this finding to the fact that pre-emptive power also conveys bargaining power, which renders other solutions like licensing or the sale/acquisition of patents more attractive to a potential acquirer (Graff et al., 2003). Consequently, we would not observe an acquisition in our data. We thank an anonymous reviewer for this remark.
} 
innovation performance, our research suggests that capturing the benefits of complementarity may be difficult, if not impossible, unless the acquirer owns the respective property rights. In that sense, it is the target's pre-emptive power that allows the acquirer to capture value.

Our findings support this hypothesis. We find that acquirers are willing to pay a higher price for the target's pre-emptive power since they expect to capture a higher share of the value created. Pre-emptive patents are therefore not attractive because they allow firms to learn but because they can be used to threaten competitors in technology areas and to secure market exclusion and the acquirer's freedom to operate in R\&D. Moreover, these patents might help firms to unlock an existing patent fence that hinders the acquirer from commercializing its own technology. The expected value capture is particularly high when acquirers are technology intensive and when the target's pre-emptive power is highly related to the acquirer's knowledge base. In that sense, our research disentangles the pre-emptive power of a firm's patent portfolio from its knowledge base and reveals the conditions under which an acquisition of technology serves not only a value creation but also a value capture motive. These findings have implications for both management practice and research.

\section{Implications for management practice}

Prior research on technology acquisitions argues that acquiring firms should "search for, identify, and acquire businesses that have scientific and technological knowledge that is complementary to their own” (Makri et al., 2010: 620). While this finding is undisputed, it requires qualification to reflect corporate reality. Firms also need the ability to capture the value they create (Saloner, Shepard, and Podolny, 2001). It is equally important for firms to understand the conditions under which the acquisition of technology helps to capture value by exploiting the target firm's pre- 
emptive power on the acquirer's resources and knowledge base. The findings suggest that a firm might miss significant value capture opportunities that stem from acquiring related patents with high pre-emptive power if an overly strong focus is put on the opportunities for learning and cross-fertilization. Our results imply that a more nuanced understanding of the sources of value is required in order to identify value creation and value capture opportunities for acquiring firms.

The analysis also implies that firms need to keep a careful eye on the key technologies in their industry and identify the associated intellectual property rights. M\&A transactions may not only lead to a concentration of market power in product markets but also to a concentration of patents with high pre-emptive power that threaten a firm's freedom to operate in $R \& D$ and, as a consequence, its value capture opportunities. As a response, firms should license-in potentially critical patents before a change in ownership occurs through M\&A.

\section{Implications for research}

Our research underlines that a patent portfolio not only provides an observable indicator of a firm’s technological capabilities (Henderson and Cockburn, 1994; Adegbesan and Higgins, 2010) but that it also holds pre-emptive power. In this regard, the pre-emptive power of a patent portfolio constitutes a source of value in itself that is distinct from the value of the firm's knowledge base. Hence, we contribute to research on value appropriation, which has remained a relatively understudied area in the RBV (Coff, 1999; Barney, 2001). We also contribute to SFM theory by clarifying an implicit, yet important assumption regarding the appropriation of value in the presence of heterogeneous resource complementarity. Since many firms are active in SFM where acquiring firms differ in their complementarity to target resources, SFM theory argues that those firms that display superior complementarity can be guaranteed a minimum level of value 
appropriation (Adegbesan, 2009). This reasoning overlooks the fact that firms might not possess the property rights necessary to commercially exploit resource complementarities and hence to capture the value created. In that sense, we extend SFM theory by incorporating insights from property rights economics, which has been argued to enrich research in the broader context of the RBV (Foss and Foss, 2005). Furthermore, our research sheds new light on a common belief in the strategy literature that inimitable and non-substitutable resources protect firms' ability to appropriate value from such resources (Barney, 1991). In fact, superior complementarity to resources on SFM may be perfectly inimitable and non-substitutable by competitors, but firms may still be hindered from capturing value because competitors possess essential property rights. In that sense, we underline that the protection of resource value goes beyond making resources difficult to imitate and substitute by competitors. We show that a firm's decision making on the acquisition price takes exactly this into account in that the price paid for an acquisition target is driven by the acquirer's expectation to both create and capture value. Our research thus also shows that property rights on resources may be a second source of value that extant theoretical and empirical literature on SFM has failed to document.

Since patents represent both the successful outcome of an R\&D investment and an intellectual property right to exclude third parties from the commercialization of an invention, a major challenge lies in the identification of a patent portfolio's pre-emptive power as a separate value component in addition to the technological value of the underlying knowledge. The application of new measures presented here informs future research that aims at uncovering the components leading to value creation and value capture. The measures build on unique information available from the patent examination procedure at the EPO (Guellec et al., 2012). In that regard, the measures can be used in research to gain an overview of "who competes with 
whom” in technology areas. Compared to alternative measures of competition and infringement in technology markets, such as litigations and oppositions ${ }^{15}$ (only at the EPO), XY-type citations occur at a much earlier stage of the patenting procedure, i.e. after the patent application. Significant opposition costs, consisting largely of lawyers' salaries, and much higher litigation costs (Harhoff and Reitzig, 2004) lead to a low opposition rate and an even lower litigation rate (Lanjouw and Schankerman, 2001). In fact, it has been shown that oppositions are only a good measure of competition in some industries (Hall and Harhoff, 2004). Citations at the EPO, however, are added in the patent examination process and hence potentially infringing patents can be identified at a very early stage of the patent application procedure, without incurring any additional costs for the patent holder or potential infringer. ${ }^{16}$ In this regard, XY-type citations can also be used by competition authorities to evaluate the concentration of pre-emptive power in technology markets. While the pre-emptive use of patents has received special attention in the clearance of Google’s acquisition of Motorola by both the U.S. and European competition authorities, there does not yet seem to be any systematic approach towards competition issues in technology fields. ${ }^{17}$

\footnotetext{
${ }^{15}$ Oppositions constitute patent validity claims before court. They are not as costly for the opponents as litigations (Hall and Harhoff, 2004).

${ }^{16}$ Hall and Harhoff (2004) show that patent applications with more patent references to prior art threatening their novelty are more likely to be opposed after being granted.

${ }^{17}$ See an interview with Joaquin Almunia, Vice President of the European Commission and Commissioner for Competition, on the Motorola acquisition and the pre-emptive use of patents: http://www.vieuws.eu/issues/1-eu-competition/15-eucompetition/287-exclusive-interview-with-commissioner-for-competition-almunia-on-ipr-patents/
} 


\section{CONCLUDING REMARKS}

Our research draws on a comprehensive longitudinal dataset of 1428 firm acquisitions in Europe during the 14-year period from 1997 to 2010 to investigate the conditions under which technology acquisitions allow firms to create and capture value. Nevertheless, we need to acknowledge several limitations. First, patent-based measures are subject to industry differences in the likelihood of patenting. Some industries exhibit a higher fraction of unpatented inventions than other industries (Mansfield, 1986), although the importance of patenting has grown rapidly in many industries in recent years, including industries outside the manufacturing sector (Makri et al., 2010). Second, the measures to identify the technological value of the knowledge base and the pre-emptive power of patent portfolios can only be applied to EPO patents as the EPO publishes an examination report indicating the importance of references to patented prior art. Third, in this study we cannot account for the fact that acquiring firms might aim at the preemptive power of a target firm's patent portfolio because of an existing patent fence that the acquirer wants to unlock or because the acquirer wants to pro-actively threaten other firms' technology development activities in a certain technology area. However, this distinction is likely to be best analyzed through case studies as an in-depth knowledge of the technologies involved is required. Overall, this study suggests that future research should further explore the different sources of value in technology acquisitions to overcome the rather narrow focus prior literature has put on investigating the opportunities for learning and cross-fertilization. In a bidding contest, potential acquirers might actually ascribe much higher value to the pre-emptive power of a target's patents. 


\section{ACKNOWLEDGEMENTS}

We thank Juan Alcacer, Oliver Alexy, Rene Belderbos, Kevin Boudreau, Bruno Cassiman, Paola Criscuolo, Bronwyn Hall, Dietmar Harhoff, Keld Laursen, Michael Leiblein, Sebastian Pacher, Ammon Salter and Reinhilde Veugelers as well as the editor, Richard Bettis, and two anonymous reviewers for valuable comments and discussions. Moreover, we thank Thorsten Doherr for data support.

\section{REFERENCES}

Adegbesan JA. 2009. On the Origins of Competitive Advantage: Strategic Factor Markets and Heterogeneous Resource Complementarity. Academy of Management Review 34(3): 463475.

Adegbesan JA, Higgins MJ. 2010. The Intra-Alliance Division of Value Created through Collaboration. Strategic Management Journal 32: 187-211.

Ahuja G, Katila R. 2001. Technological Acquisitions and the Innovation Performance of Acquiring Firms: A Longitudinal Study. Strategic Management Journal 22(3): 197-220.

Aiken LS, West SG. 1991. Multiple Regression. Testing and Interpreting Interactions: Newbury Park et al.

Alchian AA, Demsetz H. 1973. The Property Rights Paradigm. Journal of Economic History 33: $16-27$.

Arrow KJ. 1962. Economic Welfare and the Allocation of Resources for Invention. In RR Nelson (Ed.), The Rate and Direction of Inventive Activity: Economic and Social Factors: Princeton, NJ: 609-625.

Barney JB. 1986. Strategic Factor Markets. Expectations, Luck, and Business Strategy. Management Science 32(10): 1231-1241.

Barney JB. 1988. Returns to Bidding Firms in Mergers and Acquisitions: Reconsidering the Relatedness Hypothesis. Strategic Management Journal 9: 71-78.

Barney JB. 1991. Firm Resources and Sustained Competitive Advantage. Journal of Management 17(1): 99-120.

Barney JB. 2001. Resource-Based Theories of Competitive Advantage: A Ten-Year Retrospective on the Resource-Based View. Journal of Management 27(6): 643-650.

Blind K, Cremers K, Müller E. 2009. The Influence of Strategic Patenting on Companies' Patent Portfolios. Research Policy 38(2): 428-436.

Brandenburger AM, Stuart H, W. 1996. Value-Based Business Strategy. Journal of Economics and Management Strategy 5(1): 5-24.

Cardinal LB, Miller CC, Palich LE. 2011. Breaking the Cycle of Iteration: Forensic Failures of International Diversification and Firm Performance Research. Global Strategy Journal 1: 175-186.

Cassiman B, Colombo MG, Garrone P, Veugelers R. 2005. The Impact of M\&a on the R\&D Process. An Empirical Analysis of the Role of Technological- and Market-Relatedness. Research Policy 34: 195-220.

Ceccagnoli M. 2009. Appropriability, Preemption, and Firm Performance. Strategic Management Journal 30(1): 81-98. 
Cloodt M, Hagedoorn J, van Kranenburg H. 2006. Mergers and Acquisitions: Their Effect on the Innovative Performance of Companies in High-Tech Industries. Research Policy 35: 642654.

Cockburn I, MacGarvie MJ. 2011. Entry and Patenting in the Software Industry. Management Science 57: 915-933.

Coff RW. 1999. When Competitive Advantage Doesn't Lead to Performance: The ResourceBased View and Stakeholder Bargaining Power. Organization Science 10(2): 119-133.

Cohen WM, Goto A, Nagata A, Nelson RR, Walsh JP. 2002. R\&D Spillovers, Patents and the Incentives to Innovate in Japan and the United States. Resarch Policy 31: 1349-1367.

Cohen WM, Levinthal DA. 1990. Absorptive Capacity: A New Perspective on Learning and Innovation. Administrative Science Quarterly 35(1): 128-152.

Cohen WM, Nelson RR, Walsh JP. 2000. Protecting Their Intellectual Assets: Appropriability Conditions and Why U.S. Manufacturing Firms Patent (or Not), NBER Working Paper: Cambridge, MA.

Conner KR. 1991. A Historical Comparison of Resource-Based Theory and Five Schools of Thought within Industrial Organization Economics. Do We Have a New Theory of the Firm? Journal of Management 17(1): 121-154.

Criscuolo P, Verspagen B. 2008. Does It Matter Where Patent Citations Come From? Inventor Vs. Examiner Citations in European Patents. Resarch Policy 37: 1892-1908.

Czarnitzki D, Hussinger K, Leten B. 2011. The Market Value of Blocking Patent Citations, ZEW Discussion Paper: Mannheim.

Dernis H, Khan M. 2004. Triadic Patent Families Methodology, OECD Science, Technology and Industry Working Papers: Paris.

Foss K, Foss NJ. 2005. Resources and Transaction Costs: How Property Rights Economics Furthers the Resource-Based View. Strategic Management Journal 26: 541-553.

Gambardella A, Harhoff D, Verspagen B. 2008. The Value of Patents. European Management Review 5(2): 69-84.

Graebner M. 2004. Momentum and Serendipity: How Acquired Leaders Create Value in the Integration of Technology Firms. Strategic Management Journal 25: 751-777.

Graff GD, Rausser GC, Small AA. 2003. Agricultural Biotechnology's Complementary Intellectual Assets. The Review of Economics and Statistics 85(2): 349-363.

Grimpe C, Hussinger K. 2008. Pre-Empting Technology Competition through Firm Acquisitions. Economics Letters 100(2): 189-191.

Grimpe C, Kaiser U. 2010. Balancing Internal and External Knowledge Acquisition: The Gains and Pains from R\&D Outsourcing. Journal of Management Studies 47(8): 1483-1509.

Guellec D, Martinez C, Zuniga MP. 2012. Pre-Emptive Patenting: Securing Market Exclusion and Freedom of Operation. Economics of Innovation and New Technology 21(1): 1-29.

Hall BH. 1990. The Impact of Corporate Restructuring on Industrial Research and Development. Brookings Papers on Economic Activity 1990: 85-124.

Hall BH, Harhoff D. 2004. Post-Grant Reviews in the U.S. Patent System: Design Choices and Expected Impact. Berkeley Technology Law Journal 19(3): 989-1015.

Hall BH, Jaffe AB, Trajtenberg M. 2005. Market Value and Patent Citations. RAND Journal of Economics(Spring): 16-38.

Harhoff D, Hoisl K, Webb C. 2005. Analysing European and International Patent Citations: A Set of Epo Patent Database Building Blocks, OECD STI Working Paper 2005/9: Paris. 
Harhoff D, Narin F, Scherer FM, Vopel K. 1999. Citation Frequency and the Value of Patented Inventions. The Review of Economics and Statistics 81(3): 511-515.

Harhoff D, Reitzig M. 2004. Determinants of Opposition against Epo Patent Grants - the Case of Biotechnology and Pharmaceuticals. International Journal of Industrial Organization 22(4): 443-480.

Harhoff D, von Graevenitz G, Wagner S. 2008. Incidence and Growth of Patent Thickets: The Impact of Technological Opportunities and Complexity, CEPR Discussion Paper: London.

Henderson R, Cockburn I. 1994. Measuring Competence? Exploring Firm Effects in Pharmaceutical Research. Strategic Management Journal 15(8): 63-84.

Hitt M, Bierman L, Uhlenbruck K, Shimizu K. 2006. The Importance of Resources for the Internationalization of Professional Service Firms: The Good, the Bad and the Ugly. Academy of Management Journal 49: 1137-1157.

Hitt MA, Harrison JS, Ireland RD. 2001. Mergers and Acquisitions: A Guide to Creating Value for Shareholders. Oxford University Press: New York.

Hitt MA, Hoskisson RE, Johnson RA, Moesel DD. 1996. The Market for Corporate Control and Firm Innovation. Academy of Management Journal 39(5): 1084-1119.

Jaffe AB. 1986. Technological Opportunity and Spillovers of R\&D: Evidence from Firms' Patents, Profits, and Market Values. American Economic Review 76(5): 984-1001.

Kogut R, Zander U. 1992. Knowledge of the Firm, Combinative Capabilities and the Replication of Technology. Organization Science 33(3): 383-397.

Lanjouw JO, Schankerman M. 2001. Characteristics of Patent Litigation: A Window on Competition. RAND Journal of Economics 32(1): 129-151.

Lippman SA, Rumelt RP. 2003. A Bargaining Perspective on Resource Advantage. Strategic Management Journal 24: 1069-1086.

Makri M, Hitt MA, Lane PJ. 2010. Complementary Technologies, Knowledge Relatedness, and Invention Outcomes in High Technology Mergers and Acquisitions. Strategic Management Journal 31: 602-628.

Mansfield E. 1986. Patents and Innovation. An Empirical Study. Management Science 32(2): 173-181.

Michel J, Bettels B. 2001. Patent Citation Analysis. Scientometrics 51(1): 185-201.

Oriani R, Sobrero M. 2008. Uncertainty and the Market Valuation of R\&D within a Real Options Logic. Strategic Management Journal 29: 343-361.

Peteraf MA. 1993. The Cornerstones of Competitive Advantage: A Resource-Based View. Strategic Management Journal 14(3): 179-191.

Rothaermel FT, Boeker W. 2008. Old Technology Meets New Technology: Complementarities, Similarities, and Alliance Formation. Strategic Management Journal 29(1): 47-77.

Saloner G, Shepard A, Podolny J. 2001. Strategic Management. John Wiley and Sons, Inc.: New York.

Teece DJ. 1986. Profiting from Technological Innovation. Implications for Integration, Collaboration, Licensing and Public Policy. Research Policy 15: 285-305.

Trajtenberg M. 1990. A Penny for Your Quotes: Patent Citations and the Value of Innovation. RAND Journal of Economics 21(1): 172-187.

Ziedonis RH. 2004. Don't Fence Me In: Fragmented Markets for Technology and the Patent Acquisition Strategies of Firms. Management Science 50(6): 804-820. 


\section{FIGURES}

Figure 1: Patent application procedure at the EPO

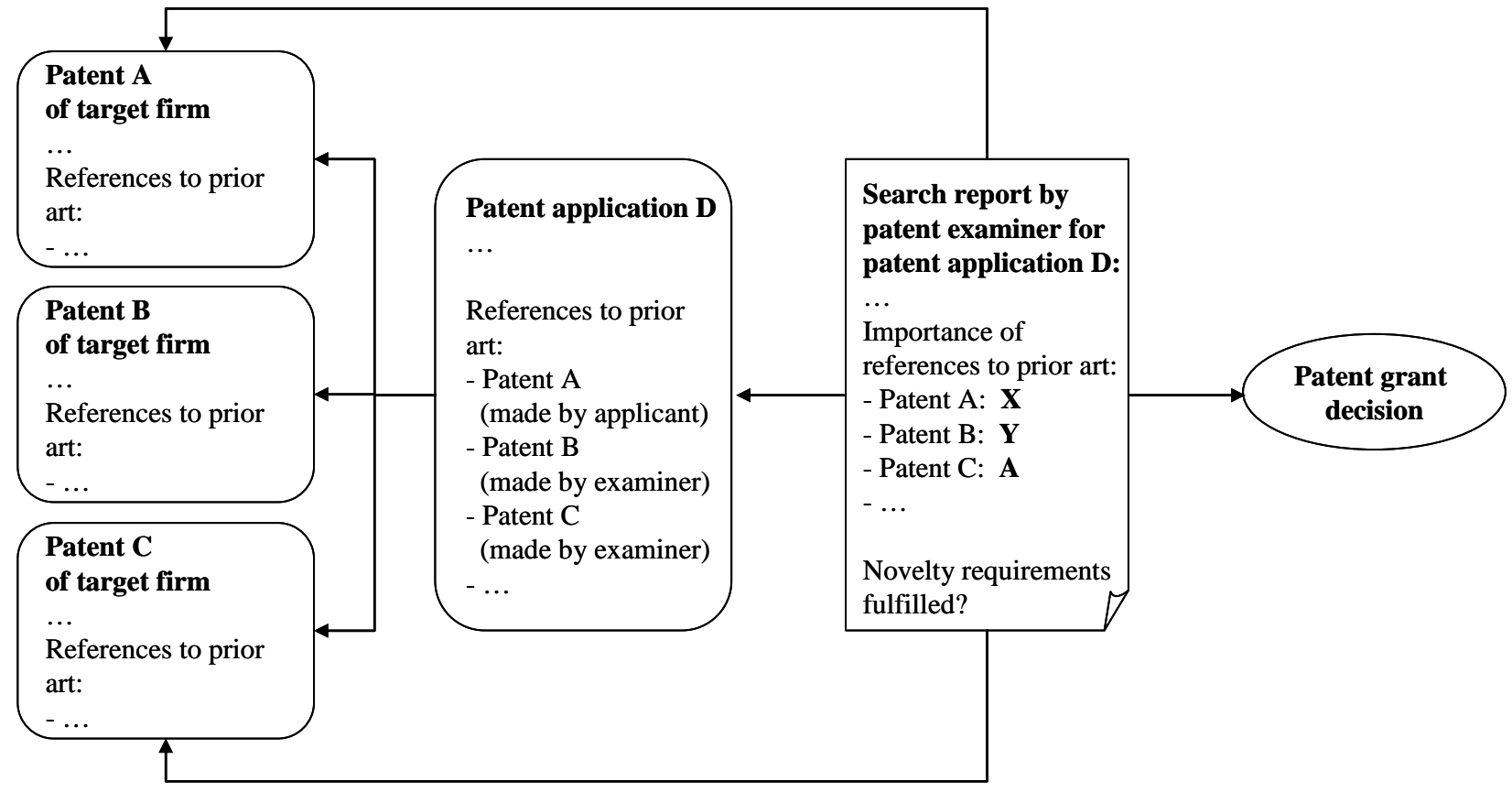

Figure 2: Estimated effect of the relatedness of acquirer's and target's patent portolios

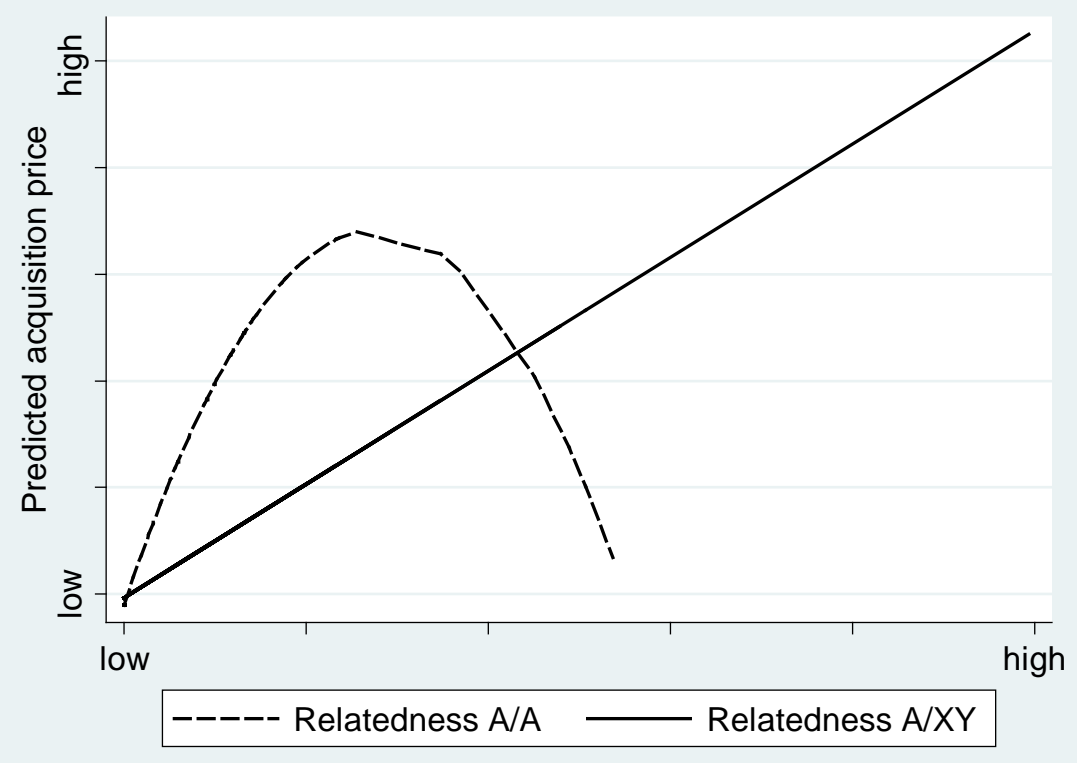




\section{TABLES}

Table 1: Summary statistics

\begin{tabular}{|c|c|c|c|c|c|c|c|c|c|c|c|c|c|c|c|c|}
\hline & & Mean & St.dev. & $1 *$ & 2 & 3 & 4 & 5 & 6 & 7 & 8 & 9 & 10 & 11 & 12 & 13 \\
\hline 1 & Acquisition price (M EUR) & 457.84 & 2034.72 & 1.00 & & & & & & & & & & & & \\
\hline 2 & Target total assets (M EUR) & 684.34 & 2380.88 & 0.36 & 1.00 & & & & & & & & & & & \\
\hline 3 & Target patent stock/total assets & 0.07 & 0.14 & -0.09 & -0.06 & 1.00 & & & & & & & & & & \\
\hline 4 & Target citation stock/patent stock & 0.86 & 1.80 & 0.13 & 0.11 & 0.15 & 1.00 & & & & & & & & & \\
\hline 5 & Target XY-citation stock/citation stock & 0.05 & 0.14 & 0.13 & 0.11 & 0.13 & 0.37 & 1.00 & & & & & & & & \\
\hline 6 & Relatedness all patents & 1.86 & 8.77 & 0.09 & 0.03 & 0.02 & 0.18 & 0.12 & 1.00 & & & & & & & \\
\hline 7 & Relatedness A-cited/A-cited patents & 0.74 & 2.19 & 0.18 & 0.07 & 0.05 & 0.31 & 0.16 & 0.22 & 1.00 & & & & & & \\
\hline 8 & Relatedness A-cited/XY-cited patents & 0.74 & 2.41 & 0.16 & 0.06 & 0.03 & 0.15 & 0.25 & 0.25 & 0.63 & 1.00 & & & & & \\
\hline 9 & Cross-border acquisition (d) & 0.43 & 0.50 & 0.10 & 0.04 & -0.05 & -0.01 & -0.03 & 0.02 & 0.04 & 0.05 & 1.00 & & & & \\
\hline 10 & Same industry acquisition (d) & 0.45 & 0.50 & 0.05 & 0.02 & -0.09 & -0.02 & 0.03 & 0.01 & 0.03 & 0.04 & 0.19 & 1.00 & & & \\
\hline 11 & Target firm age (years) & 33.66 & 40.77 & 0.15 & 0.16 & -0.04 & 0.07 & 0.03 & 0.05 & 0.03 & 0.03 & 0.02 & 0.06 & 1.00 & & \\
\hline 12 & Target return on assets & -0.04 & 0.40 & 0.12 & 0.03 & -0.21 & 0.02 & 0.05 & 0.00 & 0.02 & -0.01 & -0.00 & 0.03 & 0.06 & 1.00 & \\
\hline 13 & Target liabilities/total assets & 0.19 & 0.28 & -0.08 & -0.01 & 0.01 & 0.02 & 0.04 & 0.06 & -0.03 & 0.02 & 0.06 & -0.02 & -0.01 & 0.08 & 1.00 \\
\hline 14 & Acquirer patent stock/total assets & 0.03 & 0.30 & 0.01 & 0.02 & 0.07 & 0.03 & -0.02 & 0.00 & 0.02 & 0.00 & -0.02 & 0.01 & 0.01 & -0.02 & -0.02 \\
\hline
\end{tabular}

$\mathrm{n}=1428$; (d) dummy variable

* correlation coefficients are calculated with the acquisition price in logarithm as used in the regressions. 
Table 2: OLS regression for the acquisition price

\begin{tabular}{|c|c|c|c|c|c|c|c|}
\hline & Model 1 & Model 2 & Model 3 & Model 4 & Model 5 & Model 6 & Model 7 \\
\hline Target total assets & $\begin{array}{c}0.00^{* * *} \\
(0.00)\end{array}$ & $\begin{array}{c}0.00^{* * *} \\
(0.00)\end{array}$ & $\begin{array}{c}0.00^{* * *} \\
(0.00)\end{array}$ & $\begin{array}{c}0.00^{* * *} \\
(0.00)\end{array}$ & $\begin{array}{c}0.00^{* * *} \\
(0.00)\end{array}$ & $\begin{array}{c}0.00^{* * * *} \\
(0.00)\end{array}$ & $\begin{array}{c}0.00 * * * \\
(0.00)\end{array}$ \\
\hline Target patent stock/total assets & $\begin{array}{c}-1.04 * * \\
(0.46)\end{array}$ & $\begin{array}{c}-1.18^{* * *} \\
(0.47)\end{array}$ & $\begin{array}{c}-1.34 * * * \\
(0.46)\end{array}$ & $\begin{array}{c}-1.15^{* *} \\
(0.46)\end{array}$ & $\begin{array}{c}-1.32 * * * \\
(0.45)\end{array}$ & $\begin{array}{c}-1.32 * * * \\
(0.45)\end{array}$ & $\begin{array}{c}-1.42^{* * *} \\
(0.45)\end{array}$ \\
\hline Target citation stock/patent stock & $\begin{array}{c}0.17^{* * *} \\
(0.05)\end{array}$ & $\begin{array}{c}0.12^{* *} \\
(0.05)\end{array}$ & $\begin{array}{c}0.11^{* *} \\
(0.05)\end{array}$ & $\begin{array}{c}0.06 \\
(0.05)\end{array}$ & $\begin{array}{c}0.07 \\
(0.05)\end{array}$ & $\begin{array}{c}0.07 \\
(0.05)\end{array}$ & $\begin{array}{c}0.07 \\
(0.05)\end{array}$ \\
\hline Cross-border acquisition (d) & $\begin{array}{c}0.47^{* * *} \\
(0.12)\end{array}$ & $\begin{array}{c}0.48^{* * *} \\
(0.12)\end{array}$ & $\begin{array}{c}0.48^{* * *} \\
(0.12)\end{array}$ & $\begin{array}{c}0.43^{* * *} \\
(0.12)\end{array}$ & $\begin{array}{c}0.43^{* * * *} \\
(0.12)\end{array}$ & $\begin{array}{c}0.44^{* * * *} \\
(0.12)\end{array}$ & $\begin{array}{c}0.44^{* * * *} \\
(0.12)\end{array}$ \\
\hline Same industry acquisition (d) & $\begin{array}{c}0.07 \\
(0.12)\end{array}$ & $\begin{array}{c}0.05 \\
(0.12)\end{array}$ & $\begin{array}{c}0.05 \\
(0.12)\end{array}$ & $\begin{array}{c}0.03 \\
(0.12)\end{array}$ & $\begin{array}{c}0.04 \\
(0.12)\end{array}$ & $\begin{array}{c}0.05 \\
(0.12)\end{array}$ & $\begin{array}{c}0.04 \\
(0.12)\end{array}$ \\
\hline Target firm age (years) & $\begin{array}{l}0.00 * * \\
(0.00)\end{array}$ & $\begin{array}{l}0.00 * * \\
(0.00)\end{array}$ & $\begin{array}{l}0.00 * * \\
(0.00)\end{array}$ & $\begin{array}{l}0.00 * * \\
(0.00)\end{array}$ & $\begin{array}{c}0.00^{* *} \\
(0.00)\end{array}$ & $\begin{array}{c}0.00^{* *} \\
(0.00)\end{array}$ & $\begin{array}{c}0.00 * * \\
(0.00)\end{array}$ \\
\hline Target return on assets & $\begin{array}{c}0.62^{* * *} \\
(0.14)\end{array}$ & $\begin{array}{c}0.60 * * * \\
(0.14)\end{array}$ & $\begin{array}{c}0.59 * * * \\
(0.14)\end{array}$ & $\begin{array}{c}0.60^{* * *} \\
(0.14)\end{array}$ & $\begin{array}{c}0.59 * * * \\
(0.14)\end{array}$ & $\begin{array}{c}0.58^{* * *} \\
(0.14)\end{array}$ & $\begin{array}{c}0.59 * * * \\
(0.14)\end{array}$ \\
\hline Target liabilities/total assets & $\begin{array}{c}-0.94 * * * \\
(0.30)\end{array}$ & $\begin{array}{c}-0.95^{* * *} \\
(0.30)\end{array}$ & $\begin{array}{c}-0.94 * * * \\
(0.30)\end{array}$ & $\begin{array}{c}-0.95 * * * \\
(0.30)\end{array}$ & $\begin{array}{c}-0.96 * * * \\
(0.30)\end{array}$ & $\begin{array}{c}-0.96 * * * \\
(0.30)\end{array}$ & $\begin{array}{c}-0.96^{* * * *} \\
(0.30)\end{array}$ \\
\hline Target liabilities missing (d) & $\begin{array}{c}-0.34^{*} \\
(0.18)\end{array}$ & $\begin{array}{c}-0.33^{*} \\
(0.18)\end{array}$ & $\begin{array}{c}-0.34^{*} \\
(0.18)\end{array}$ & $\begin{array}{c}-0.35^{*} \\
(0.18)\end{array}$ & $\begin{array}{c}-0.37 * * \\
(0.18)\end{array}$ & $\begin{array}{c}-0.37 * * \\
(0.18)\end{array}$ & $\begin{array}{c}-0.37^{* *} \\
(0.18)\end{array}$ \\
\hline $\begin{array}{l}\text { Target XY-citation stock/citation } \\
\text { stock }\end{array}$ & & $\begin{array}{c}1.12 * * * \\
(0.39)\end{array}$ & $\begin{array}{c}1.11^{* * *} \\
(0.39)\end{array}$ & $\begin{array}{l}0.83 * * \\
(0.37)\end{array}$ & $\begin{array}{l}0.74^{*} \\
(0.38)\end{array}$ & $\begin{array}{l}0.73^{*} \\
(0.38)\end{array}$ & $\begin{array}{l}0.75^{*} \\
(0.38)\end{array}$ \\
\hline Acquirer patent stock/total assets & & & $\begin{array}{c}0.05 \\
(0.13)\end{array}$ & & & & $\begin{array}{c}0.07 \\
(0.12)\end{array}$ \\
\hline $\begin{array}{l}\text { Int. target XY-cit.*acquirer patent } \\
\text { stock/total assets }\end{array}$ & & & $\begin{array}{c}5.39 * * * \\
(1.47)\end{array}$ & & & & $\begin{array}{l}3.12 * * \\
(1.43)\end{array}$ \\
\hline Relatedness all patents & & & & $\begin{array}{c}0.22 * * * \\
(0.05)\end{array}$ & & & \\
\hline Relatedness all patents (squared) & & & & $\begin{array}{c}-0.00 * * * \\
(0.00)\end{array}$ & & & \\
\hline Relatedness A-cited/A-cited patents & & & & & $\begin{array}{c}0.52 * * * \\
(0.13)\end{array}$ & $\begin{array}{l}0.43^{* *} \\
(0.17)\end{array}$ & $\begin{array}{c}0.51 * * * \\
(0.13)\end{array}$ \\
\hline $\begin{array}{l}\text { Relatedness A-cited/A-cited patents } \\
\text { (squared) }\end{array}$ & & & & & $\begin{array}{c}-0.04 * * * \\
(0.01)\end{array}$ & $\begin{array}{c}-0.03^{* *} \\
(0.01)\end{array}$ & $\begin{array}{c}-0.04^{* * *} \\
(0.01)\end{array}$ \\
\hline $\begin{array}{l}\text { Relatedness A-cited/XY-cited } \\
\text { patents }\end{array}$ & & & & & $\begin{array}{l}0.11^{* *} \\
(0.04)\end{array}$ & $\begin{array}{l}0.22^{*} \\
(0.11)\end{array}$ & $\begin{array}{l}0.11^{* *} \\
(0.04)\end{array}$ \\
\hline $\begin{array}{l}\text { Relatedness A-cited/XY-cited } \\
\text { patents (squared) }\end{array}$ & & & & & & $\begin{array}{l}-0.01 \\
(0.00)\end{array}$ & \\
\hline Constant & $\begin{array}{c}1.41 * * * \\
(0.49)\end{array}$ & $\begin{array}{c}1.40^{* * *} \\
(0.48)\end{array}$ & $\begin{array}{c}1.43^{* * *} \\
(0.48)\end{array}$ & $\begin{array}{c}1.49 * * * \\
(0.48)\end{array}$ & $\begin{array}{c}1.43^{* * *} \\
(0.50)\end{array}$ & $\begin{array}{c}1.44^{* * * *} \\
(0.50)\end{array}$ & $\begin{array}{c}1.45^{* * *} \\
(0.50)\end{array}$ \\
\hline LR-tests: year dummies & $53.61^{* * *}$ & $53.43 * * *$ & $56.67 * * *$ & $52.68 * * *$ & $52.69 * * *$ & $52.19 * * *$ & $52.62^{* * *}$ \\
\hline LR-tests: industry dummies & 6.89 & 6.99 & 4.35 & 6.42 & 8.10 & 8.22 & 8.17 \\
\hline No of observations & 1428 & 1428 & 1428 & 1428 & 1428 & 1428 & 1428 \\
\hline R-squared & 0.21 & 0.22 & 0.23 & 0.23 & 0.24 & 0.24 & 0.24 \\
\hline
\end{tabular}

